\title{
Heat, cold, cryopreservation, and wine
}

\author{
Shaun R. McCann ${ }^{1}$
}

Received: 30 July 2019 / Accepted: 1 August 2019 / Published online: 27 August 2019

C Springer Nature Limited 2019

Niente senza il vino. There is nothing without wine.

Michele Psello [1] Byzantine Greek monk, philosopher, historian. (1018-1078/1096) (Fig. 1).

The ability of glycerol to protect cells from freezing injury was discovered accidentally. The discovery by C. Polge, A. U. Smith, and A.S. Parkes in 1948 that glycerol would enable fowl spermatozoa to survive freezing to $-70{ }^{\circ} \mathrm{C}$ initiated a phase of dramatic development in the techniques we now know as "cryopreservation" [2]. The subsequent development of cryopreservation techniques has had a huge impact in many fields including transfusion medicine and haematopoietic cell preservation. Freezing injury has been shown to have two components, direct damage from the ice crystals and secondary damage caused by the increase in concentration of solutes as progressively more ice is formed. Intracellular freezing is generally lethal but can be avoided by sufficiently slow cooling, and under usual conditions solute damage dominates. However, extracellular ice plays a major role in tissues. Cryoprotectants act primarily by reducing the amount of ice that is formed at any given subzero temperature [2]. A number of other agents in addition to glycerol are important including DMSO, pentastarch, hexastarch, etc.

Cryopreservation of red blood cell concentrates (RBCs) is an important method for maintaining an inventory of rare RBC units and managing special transfusion circumstances. The permeating additive glycerol is used as a cryoprotectant to protect RBCs against freezing damage. In 2014, Lagerberg published a method using a functionally closed system for the glycerolization and deglycerolization of RBC units, which extended post-thaw storage [3]. In a recent review, Blake and

Shaun R. McCann

shaunrmccann@gmail.com

1 Emeritus Haematology-School of Medicine, University of Dublin Trinity College, Dublin, Ireland

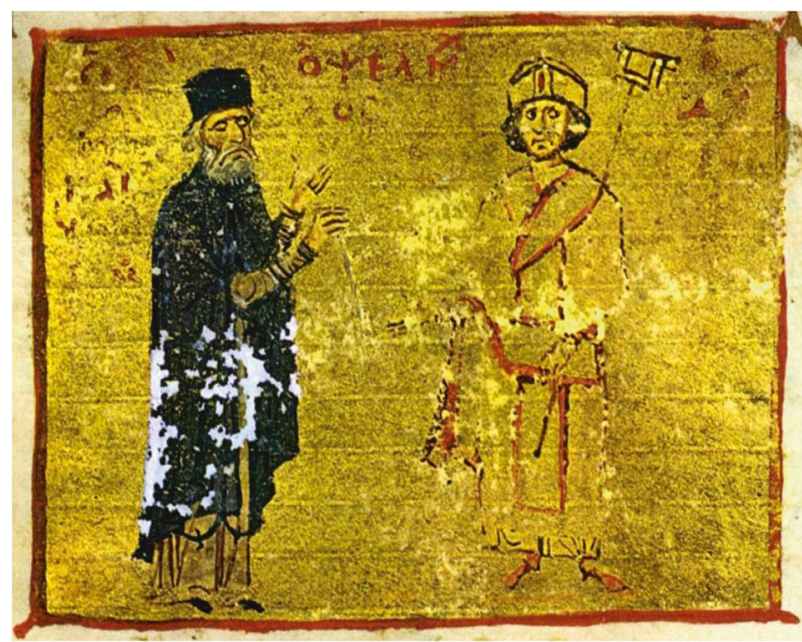

Fig. 1 Michele Psello with his student Byzantine Emperor, MichaelV11 Doukas. Codex 234, f 245a, Mount Athos, Pankrator Monastery

Clarke suggest that although cryopreservation of red cells is needed for rare blood groups large inventories do not improve access. Modest amounts of frozen inventory, combined with increased donor screening, provide the greatest chance of maximizing patient access [4]. Some military preserve platelets in DMSO as they may be better for the treatment of traumatic injury (personal communication D O'D IBTS).

Cryopreservation of cord blood (UBC) is done by cryopreservation of processed UBC units in an automated microprocessor-controlled rate freezer. After the WBC is chilled the cold freezing cryopreservative solution containing $60 \%$ DMSO is added drop wise for $15 \mathrm{~min}$. Samples for quality control of cryopreservation procedure are then extracted before freezing and cryopreserved into cryotubes with the bag. The cells will then be immediately placed inside aluminum cassettes in the chamber of the cell freezer, which uses two thermocouple probes placed in a sample containing the freezing material. The use of plates is necessary to ensure rapid and uniform freezing. The cryopreservation methodology is by $1{ }^{\circ} \mathrm{C} / \mathrm{min}$ cooling down to $-60{ }^{\circ} \mathrm{C}$, followed by a drop to $-120^{\circ} \mathrm{C}, 5^{\circ} \mathrm{C} / \mathrm{min}$. At the 


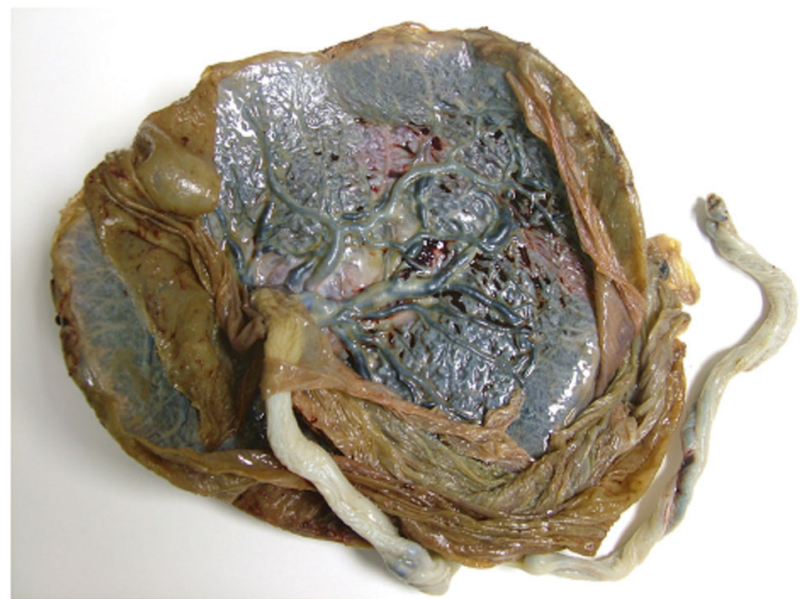

Fig. 2 Human placenta. Courtesy Prof. John O’ Leary

end of the freezing procedure the cells are stored in liquid nitrogen freezer. Immunophenotyping of the CD34+ cell estimation is carried out on the whole blood before starting the processing and volume reduction. The $\mathrm{CD} 34+$ cell number is calculated on the amount of the WBC units present after the processing The debate about the use of cord blood for haematopoietic cell transplant and whether cord blood banks should be private or public is beyond the scope of this editorial but suffice to say freezing and thawing of umbilical cord blood has been shown to effectively reconstitute human bone marrow [5, 6] (Fig. 2).

The world of obstetrics has been using cryopreserved embryos and oocytes for many years and the area of regenerative medicine and animal husbandry using cryopreserved haematopoietic cells is an interesting one.

Does temperature affect wine? Yes, it does. Old fine wines are particularly sensitive to increases in temperature. Different bottles can be affected in different ways by exposure to heat even though they are the same age and come from the same grape and vineyard. Wines kept at $15.5^{\circ}$ Centigrade $\left(60^{\circ}\right.$ Fahrenheit) should be OK. When you get to $21^{\circ}\left(70^{\circ}\right.$ Fahrenheit) you could be in trouble and $26^{\circ}$ $\left(80^{\circ}\right.$ Farenheit) is definitely catastrophic. If you are shipping wine try to make sure that it is not exposed to high temperatures and never leave cases of wine in the boot (trunk) of your car on a hot day. If you have the money invest in a wine storage system with light and temperature control (Fig. 3). Most people drink red wine at room temperature but the French sometimes cool red wines from Beaujolais and Burgundy in the fridge before drinking. Remember, as we said before, the quickest way to cool a bottle of white wine is to put it in a bucket of water and ice (50/50\%). When you get down to the last $50-60 \mathrm{ml}$ it is probably best to remove the bottle from the cooling bucket as the wine may become too cold and the taste diminished.

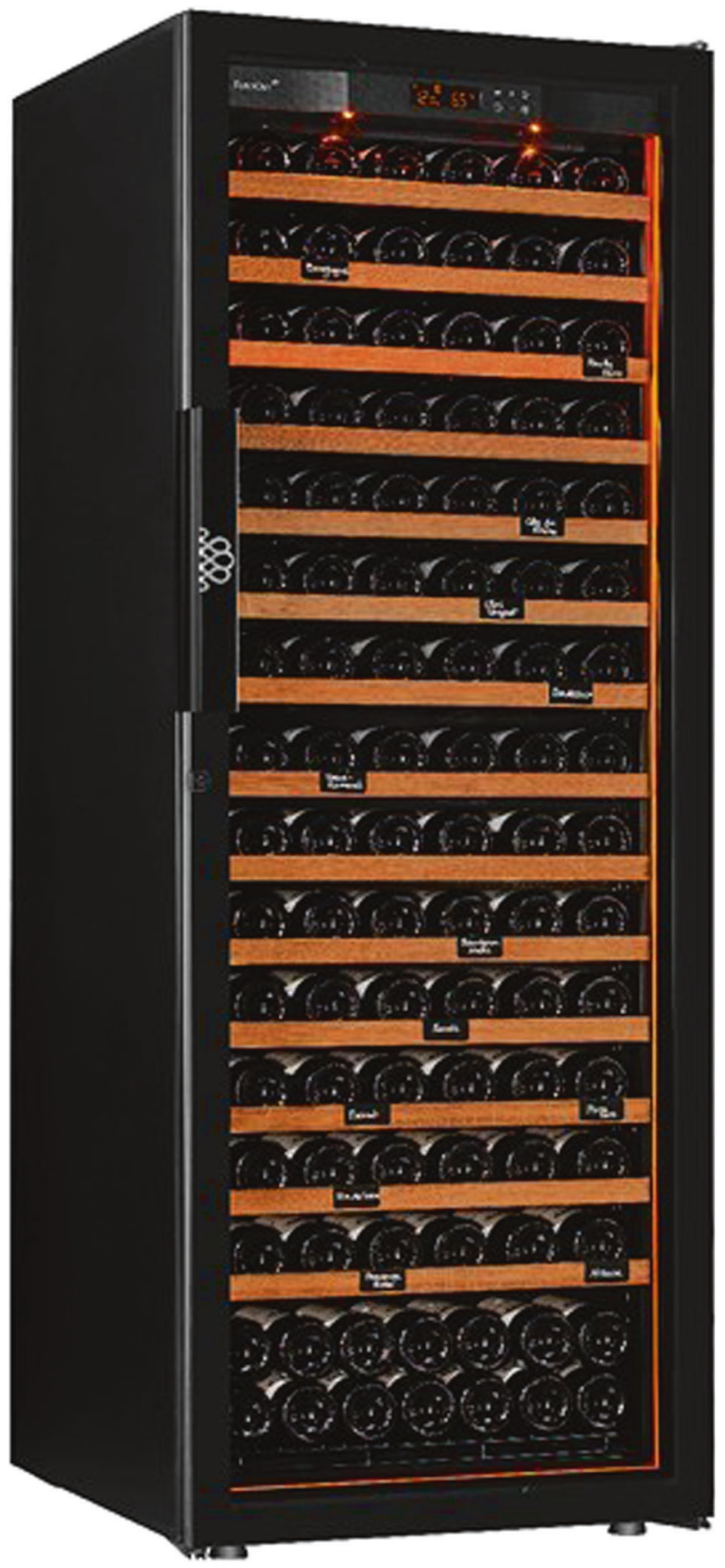

Fig. 3 A wine storage system

When a bottle of wine freezes the cork may be pushed out (Fig. 4). Air can creep in through the cracks and oxidize the wine, turning it to vinegar over time. Oxidation can also occur with screw tops if the liquid reaches the rim and breaks its airtight seal. Freezing a bottle also causes its tartrates (see bmt. https://doi.org/10.1038/s41409-0180385-0) to crystallize. If you freeze a bottle it shouldn't harm the wine's flavor. Never put a bottle of sparkling wine in the freezer: it might explode. 


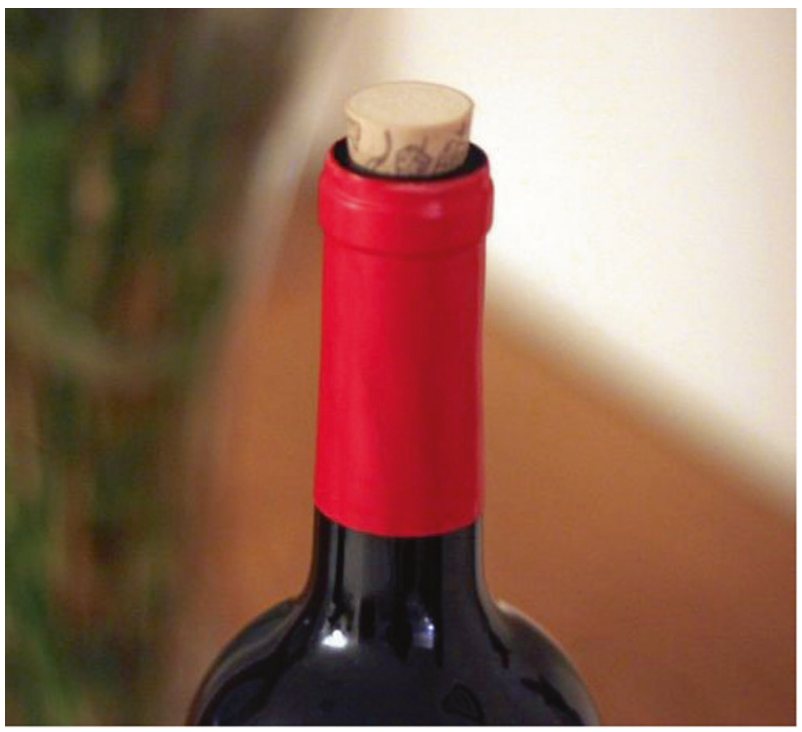

Fig. 4 Cork protrusion after exposure to excessive heat

A rise in temperature in patients usually signifies infection while a dramatic reduction in temperature "in vitro" facilitates the preservation of haemopoietic tissue indefinitely. Wines, like humans, are sensitive and should be kept at an even temperature to preserve their unique characteristics.

\section{Compliance with ethical standards}

Conflict of interest The author declares that he has no conflict of interest.

Publisher's note: Springer Nature remains neutral with regard to jurisdictional claims in published maps and institutional affiliations.

\section{References}

1. Coco L, Michele Psello. Encomio del vino, laus vini. Florence, Italy: Leo S. Olschki; 2018.

2. Pegg DE. The history and principles of cryopreservation. Semin Reprod Med. 2002;20:005-14. https://doi.org/10.1055/s-2002-23515.

3. Lagerberg JW. Cryopreservation of red blood cells. In: Wolkers W, Oldenhof $\mathrm{H}$, editors. Cryopreservation and freeze-drying protocols. Methods in molecular biology (methods and protocols), vol 1257. New York: Springer; 2015.

4. Blake JT, Clarke G. Modelling rare blood in Canada. Transfusion. 2019;59:582-92.

5. Shu Z, Heimfeld S, Gao D. Hematopoietic SCT with cryopreserved grafts: adverse reactions after transplantation and cryoprotectant removal before infusion. Bone Marrow Transpl. 2014;49:469-76. https://doi.org/10.1038/bmt.2013.152. Epub 2013. Sep 30. Review. PubMed PMID: 24076548; PubMed Central PMCID: PMC4420483.

6. Sivakumaran N, RathnayakaI. R, Shabbir R, Wimalsinghe SS, Jakody JAS, Chandrasekaran M. Umbilical cord blood banking and its therapeutic use. Int Sci Res Innov Technol. 2018;1:160-72. 5 